\section{Stockholm International Peace Research Institute (SIPRI)}

Founded in 1966 by the Swedish parliament. Independent international institute dedicated to research into conflict, armaments, arms control and disarmament. Compiles detailed studies on multilateral peace operations, military expenditure, arms transfers and arms embargoes.

Address: Signalistgatan 9, SE-169 72 Solna, Sweden.

Website: http://www.sipri.org

Director: Dan Smith.

\section{Transparency International}

Founded 1993. Non-partisan global civil society organization seeking to create change towards a world free of corruption. Global priorities: combating corruption in politics, public contracting and the private sector; international anti-corruption conventions; poverty and development.

Address: Alt-Moabit 96, 10559 Berlin, Germany.

Website: http://www.transparency.org

Chair of the Board of Directors: Delia Ferreira Rubio.

\section{Urban Institute}

Founded 1968. Independent think tank founded by the Lyndon B. Johnson administration committed to developing evidence-based insights into the efficiency of government programmes. The organization conducts impartial data research on issues including taxes, health and health policy, housing and housing finance, economic growth and productivity, immigration, education and poverty.

Address: 2100 M St., NW, Washington, D.C., 20037, USA.

Website: https://www.urban.org

President: Sarah Rosen Wartell.

\section{Woodrow Wilson International Center for Scholars}

Founded in 1968 by an act of Congress as a memorial to former US president Woodrow Wilson. Non-partisan, it promotes and develops relations between policy-makers and academic scholars. Research covers most public policy areas, specializing in the field of international affairs.

Address: One Woodrow Wilson Plaza, 1300 Pennsylvania Ave., NW, Washington, D.C., 20004-3027, USA.

Website: http://www.wilsoncenter.org

Director, President and Chief Executive Officer: Jane Harman. 